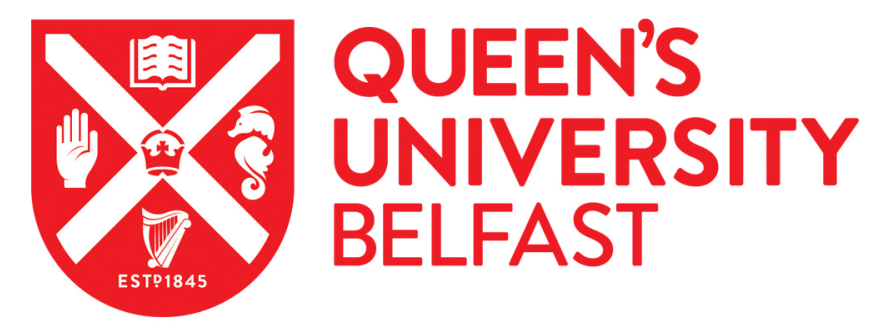

\title{
Point-of-care testing in Paediatric settings in the UK and Ireland: a cross-sectional study
}

Pandey, M., Lyttle, M. D., Cathie, K., Munro, A., Waterfield, T., \& Roland, D. (2022). Point-of-care testing in Paediatric settings in the UK and Ireland: a cross-sectional study. BMC Emergency Medicine, 22, [6]. https://doi.org/10.1186/s12873-021-00556-7

\section{Published in:}

BMC Emergency Medicine

\section{Document Version:}

Publisher's PDF, also known as Version of record

\section{Queen's University Belfast - Research Portal:}

Link to publication record in Queen's University Belfast Research Portal

\section{Publisher rights}

Copyright 2022 the authors.

This is an open access article published under a Creative Commons Attribution License (https://creativecommons.org/licenses/by/4.0/), which permits unrestricted use, distribution and reproduction in any medium, provided the author and source are cited.

\section{General rights}

Copyright for the publications made accessible via the Queen's University Belfast Research Portal is retained by the author(s) and / or other copyright owners and it is a condition of accessing these publications that users recognise and abide by the legal requirements associated with these rights.

Take down policy

The Research Portal is Queen's institutional repository that provides access to Queen's research output. Every effort has been made to ensure that content in the Research Portal does not infringe any person's rights, or applicable UK laws. If you discover content in the Research Portal that you believe breaches copyright or violates any law, please contact openaccess@qub.ac.uk. 


\title{
Point-of-care testing in Paediatric settings in the UK and Ireland: a cross-sectional study
}

\author{
Meenu Pandey ${ }^{1}$, Mark D. Lyttle ${ }^{2,3}$, Katrina Cathie ${ }^{4}$, Alasdair Munro ${ }^{5}$, Thomas Waterfield ${ }^{6,7}$, Damian Roland ${ }^{1,8^{*}}$ and \\ On behalf of GAPRUKI, PERUKI
}

\begin{abstract}
Background: Point-of-care testing (POCT) is diagnostic testing performed at or near to the site of the patient. Understanding the current capacity, and scope, of POCT in this setting is essential in order to respond to new research evidence which may lead to wide implementation.

Methods: A cross-sectional online survey study of POCT use was conducted between 6th January and 2nd February 2020 on behalf of two United Kingdom (UK) and Ireland-based paediatric research networks (Paediatric Emergency Research UK and Ireland, and General and Adolescent Paediatric Research UK and Ireland).

Results: In total 91/109 (83.5\%) sites responded, with some respondents providing details for multiple units on their site based on network membership (139 units in total). The most commonly performed POCT were blood sugar (137/139; 98.6\%), urinalysis (134/139; 96.4\%) and blood gas analysis (132/139; 95\%). The use of POCT for Influenza/Respiratory Syncytial Virus (RSV) (45/139; 32.4\%, 41/139; 29.5\%), C-Reactive Protein (CRP) (13/139; 9.4\%), Procalcitonin (PCT) $(2 / 139 ; 1.4 \%)$ and Group A Streptococcus $(5 / 139 ; 3.6 \%)$ and was relatively low. Obstacles to the introduction of new POCT included resources and infrastructure to support test performance and quality assurance.

Conclusion: This survey demonstrates significant consensus in POCT practice in the UK and Ireland but highlights specific inequity in newer biomarkers, some which do not have support from national guidance. A clear strategy to overcome the key obstacles of funding, evidence base, and standardising variation will be essential if there is a drive toward increasing implementation of POCT.
\end{abstract}

Keywords: Technology, Molecular biology, Health services research, Data collection

\section{Background}

There is a need for clinicians to make accurate and timely decisions regarding emergency management of their patients. Laboratory tests are often used, in conjunction with clinical findings, to determine the most appropriate care pathway. Delays in obtaining and

\footnotetext{
* Correspondence: dr98@leicester.ac.uk

${ }^{1}$ Paediatric Emergency Medicine Leicester Academic (PEMLA) Group,

Children's Emergency Department, Leicester Royal Infirmary, Leicester, UK

${ }^{8}$ SAPPHIRE Group, Health Sciences, Leicester University, Leicester, UK

Full list of author information is available at the end of the article
}

reporting urgent samples can lead to department crowding, protracted discharge times, and failure to deliver optimal patient care in emergency and acute care settings [1-3]. Point-Of-Care Testing (POCT) has the potential to provide rapid and accurate results that reduce such delays [4-6]. Potential additional benefits include improved clinical management, treatment adherence, and patient satisfaction [5] which must be balanced against the clinical significance of time gained. For example, in the context of an over crowded department with long waiting times does a $15 \mathrm{~min}$ time to result improve

C C The Author(s). 2021 Open Access This article is licensed under a Creative Commons Attribution 4.0 International License, which permits use, sharing, adaptation, distribution and reproduction in any medium or format, as long as you give appropriate credit to the original author(s) and the source, provide a link to the Creative Commons licence, and indicate if changes were made. The images or other third party material in this article are included in the article's Creative Commons licence, unless indicated otherwise in a credit line to the material. If material is not included in the article's Creative Commons licence and your intended use is not permitted by statutory regulation or exceeds the permitted use, you will need to obtain permission directly from the copyright holder. To view a copy of this licence, visit http://creativecommons.org/licenses/by/4.0/ The Creative Commons Public Domain Dedication waiver (http://creativecommons.org/publicdomain/zero/1.0/) applies to the data made available in this article, unless otherwise stated in a credit line to the data. 
outcomes for patients? Also there are concerns regarding reliability and cost of POCT compared with centralised laboratory testing, and appropriate governance of POCT. There is currently no clearly described consensus approach to procurement, implementation and governance of POCT in the UK and Ireland; similar lack of consensus is evident in medical literature internationally [7-11].

However emerging evidence and ongoing research continue to evaluate the potential impact of POCT. Should these tests prove to have good clinical utility, they are likely to be incorporated into national guidance, and clinical practice, more widely. Developing a framework for the clinical use, implementation, and governance of POCT is therefore essential within the healthcare system, especially those aiming to prioritise same day emergency care. It remains the case that many Emergency Departments serve both adult and paediatric populations, and POCT may serve the needs of both patient groups. This works well for test common to both age categories (such as glucose) but perhaps not so well for respiratory testing which is anecdotally more common place in paediatric practice. As no survey of POCT has previously been performed across Children's Acute and Emergency Care, it is important to establish whether this is truly the case, across a widely inclusive range of POCTs.

The primary aim of this study was to describe POCT in current use in acute paediatric settings across the UK and Ireland. Secondary objectives were to examine implementation, maintenance, funding and governance and further opinions on the introduction of new POCT including obstacles and enablers.

\section{Methods}

This online cross sectional survey was conducted between 6th January and 2nd February 2020, and is reported in accordance with the Checklist for Reporting Results of Internet E-Surveys (CHERRIES [12]).

Existing literature on use of POCT in acute paediatric settings [9-11] informed the initial survey content, which was subsequently refined iteratively by the study team. In the absence of international guidance, content was finalised by consensus of the study team following external review, and prior to launch the survey underwent external piloting. This rationlised the number of questions and determined the range of POCTs to be surveyed. The survey was distributed to member sites of the General Adolescent and Paediatric Research in the UK \& Ireland (GAPRUKI) and Paediatric Emergency Research in the UK \& Ireland (PERUKI [13]) networks, with one response for each relevant emergency or acute paediatric unit requested from each network site (not all sites were members of both networks). Responses could be provided on behalf of Emergency Departments, Paediatric Assessment Units, Paediatric ward settings, and Urgent Care Centres.

For the purposes of this survey, POCT was defined as an investigative or diagnostic test utilised by staff in a clinical environment, for which results are available in a short time (within $30 \mathrm{~min}$ ) to aid clinical decision making in that setting (i.e. not at a later date/time). Additional detail in this definition stated that they should be performed and interpreted by clinical staff caring for the patient, not sent elsewhere for other personnel to analyse and interpret, and should require no other interpretation (i.e. the result is binary, sequential or categorical).

The full survey, available in Appendix 1, included questions on availability of a range of POCT across clinical settings. Adaptive questioning was used, and where applicable, respondents were asked questions on personnel performing and interpreting tests, and POCT governance. All respondents were asked to provide the view of their site on the potential benefits and challenges presented by the concept of expanding POCT use, and were asked to describe any obstacles or enablers from previous experience of implementing POCT.

Responses were collected in Research Electronic Data Capture tools (REDCap [14, 15]), and were held on a secure University of Bristol server. We followed a standard framework; open for 4 weeks with non-responders sent reminders with 2 weeks to go, 1 week to go, and $48 \mathrm{~h}$ to go. Responses were analysed anonymously by the study team using Microsoft Excel version 16.42). Data are presented using descriptive statistics, including number and proportion for categorical variables.

As this survey study contained no patient level data, and was distributed using professional collaborative professional networks, ethical approval was unnecessary according to the Health Research Authority framework decision tool [16] .

\section{Results}

In total, 109 invites were sent, to which there were 91 (83.5\%) responses across 139 units (Fig. 1, each clinician could respond for more than one unit on their site), contributing data regarding 72 Emergency Departments (including Observation Units), 28 Paediatric Assessment Units, 34 Paediatric Inpatient wards, and five Urgent Care Centres.

There were a range of POCT available across sites, including those available in testing modalities analysing more than one marker simultaneously (for example, blood gas analysis variables) (Table 1). The most commonly performed POCT were blood sugar measurement (137/139; 98.6\%), urinalysis (134/139; 96.4\%) and blood gas analysis (132/139; 95\%). In blood gas analysers, most sites had access to Lactate (127/139; 91.4\%), pH/PaCO2/ 


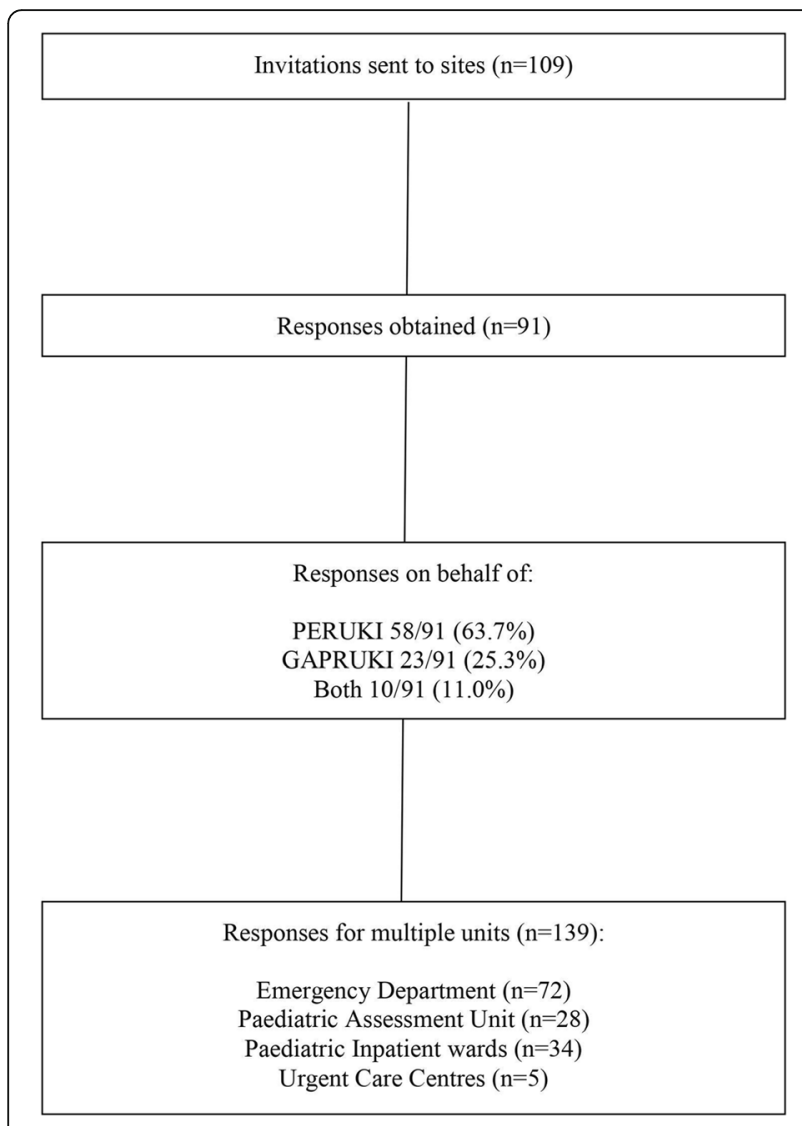

Fig. 1 Flow diagram showing the flow of responses

PaO2/Base Excess (126/139; 90.6\%), Sodium/Potassium (126/139; 90.6\%), Glucose (123/139; 88.5\%) and Haemoglobin (116/139; 83.5\%).

The use of Influenza/Respiratory Syncytial Virus (RSV) POCT were available in approximately one-third of sites (45/139; 32.4\%, and 41/139; 29.5\%, respectively), whilst availability of POCT for other biomarkers including $\mathrm{C}$ reactive protein (CRP) (13/139; 9.4\%), Group A Streptococcus $(5 / 139 ; 3.6 \%)$ and Procalcitonin (PCT) (2/139; $1.4 \%)$ was markedly lower.

A description of staff types performing and interpreting tests is provided in Table 2; this is further quantified by clinical area in Supplementary Tables 5 and 6 . As multiple staff groups could be selected for each POCT for each unit, there was a total of 2132 responses relating to staff roles in performance of POCT, and 3097 relating to actioning of results. Clinical nurses were the staff group most commonly responsible for POCT performance $(705 / 2132 ; 33.1 \%)$ followed by Emergency Nurse Practitioners (ENP)/Advanced Nurse Practitioners (ANP) $(435 / 2132,20.4 \%)$ and junior doctors (385/2132; $18.1 \%)$. POCT were mostly acted on by senior nonconsultants (736/3097; 23.8\%), consultants (736/3097; $23.8 \%)$ and junior trainees $(702 / 3097 ; 22.7 \%)$.
Information regarding the non-clinical utilisation of POCT is provided in Table 3, with 561 responses related to governance, and 677 responses related to data storage.

Most commonly, clinical staff took some responsibility for POCT governance in conjunction with laboratory teams $(346 / 561 ; 61.7 \%)$, followed by laboratory teams taking full responsibility $(186 / 561 ; 33.2 \%)$. The POCT most likely to come under shared responsibility were urinary human Chorionic Gonadotropin (hCG) (58/82; $70.7 \%$ ), urinalysis (66/94; 70.2\%), blood sugar (69/99; 69.7\%) and blood ketones (63/92; 68.5\%). POCT which give multiple results (such as blood gases) were primarily managed by laboratory teams $(53 / 99 ; 53.5 \%$,).

The most common method of data storage was handwritten notes in clinical records (241/677; 35.6\%) followed by printouts attached to medical records (180/ 677; 26.6\%) and manual entry (146/677; 21.6\%). Automatic uploading to electronic systems occurred in only $15.8 \%$ of responses $(107 / 677)$.

Obstacles to POCT introduction (158 responses), and nature of funding sources (98 responses), are displayed in Table 4. The most commonly reported obstacles were difficulties with funding $(72 / 158 ; 45.6 \%)$, lack of evidence (33/158; 20.9\%) and issues with POCT governance (20/ $158 ; 12.7 \%)$. POCT were typically funded as part of an ongoing service with sustainable long-term funding (81/ 98; 82.7\%). Other methods of funding included temporary funds as part of a service evaluation $(10 / 98 ; 10.2 \%)$, or charitable funding and/or donations (5/98; 5.1\%).

\section{Discussion}

We have demonstrated a diverse range of POCT in use in Children's Emergency Departments and Assessment units. Some POCT, such as blood sugar testing, blood ketone testing, blood gas analysis and urinalysis are fairly commonplace, whilst "newer" POCT such as CRP and Procalcitonin were uncommon. Despite this penetrance of POCT into acute units, we have also identified wide variation in their governance, and usage processes. The challenge of identifying the optimal governance of POCT appears to hinder their implementation, as do a current lack of evidence, and cost; these elements are particularly important when considering introducing POCT to national guidance if emerging evidence supports their use.

Respiratory POCT were utilised in under half the responding units, with Respiratory Syncytial Virus (RSV) and influenza usage at 33.3 and $40.3 \%$ respectively. POCT for RSV has previously been evaluated and found to be a safe, cost-effective, and efficient way to improve bed management [17]. The lack of widespread utilisation is, therefore, perhaps surprising. However, some centres cohort infants with bronchiolitis based on symptoms, in 
Table 1 Point Of Care Tests (POCT) done and investigations available on blood gas analysers

\begin{tabular}{|c|c|c|c|c|c|}
\hline POCTs & Total $(n=139)$ & $\mathrm{ED}(n=72)$ & PAU $(n=28)$ & UCC $(n=5)$ & Inpatient ward $(n=34)$ \\
\hline Blood sugar & 137/139 (98.6\%) & $72 / 72(100 \%)$ & $27 / 28(96.4 \%)$ & $5 / 5(100 \%)$ & 33/34 (97.1\%) \\
\hline Urinalysis & 134/139 (96.4\%) & 70/72 (97.2\%) & $27 / 28$ (96.4\%) & $5 / 5(100 \%)$ & $32 / 34(94.1 \%)$ \\
\hline Blood gas analysis & 132/139 (95\%) & $72 / 72(100 \%)$ & 25/28 (89.3\%) & $3 / 5(60 \%)$ & $32 / 34(94.1 \%)$ \\
\hline Blood ketones & 125/139 (89.9\%) & 66/72 (91.7\%) & 25/28 (89.3\%) & $3 / 5(60 \%)$ & $31 / 34(91.2 \%)$ \\
\hline Urinary Beta hCG & 115/139 (82.7\%) & 66/72 (91.7\%) & 20/28 (71.4\%) & $5 / 5(100 \%)$ & 24/34 (70.6\%) \\
\hline Influenza (any) & 45/139 (32.4\%) & 29/72 (40.3\%) & $7 / 28(25 \%)$ & $1 / 5(20 \%)$ & $8 / 34(23.5 \%)$ \\
\hline RSV & $41 / 139$ (29.5\%) & 24/72 (33.3\%) & $7 / 28(25 \%)$ & $1 / 5(20 \%)$ & 9/34 (26.5\%) \\
\hline Other & $17 / 139(12.2 \%)$ & 15/72 (20.8\%) & $2 / 28(7.1 \%)$ & $0 / 5(0 \%)$ & 0/34 (0\%) \\
\hline CRP & 13/139 (9.4\%) & $7 / 72(9.7 \%)$ & $3 / 28(10.7 \%)$ & $0 / 5(0 \%)$ & 3/34 (8.8\%) \\
\hline Group A Streptococcus & $5 / 139(3.6 \%)$ & $3 / 72(4.2 \%)$ & $1 / 28(3.6 \%)$ & $0 / 5(0 \%)$ & $1 / 34(2.9 \%)$ \\
\hline Procalcitonin & $2 / 139(1.4 \%)$ & $1 / 72(1.4 \%)$ & 0/28 (0\%) & 0/5 (0\%) & $1 / 34(2.9 \%)$ \\
\hline \multicolumn{6}{|c|}{ Blood gas analyser investigations available among units doing blood gases } \\
\hline Lactate & $127 / 139(91.4 \%)$ & $69 / 72(95.8 \%)$ & 25/28 (89.3\%) & $3 / 5(60 \%)$ & $30 / 34(88.2 \%)$ \\
\hline $\mathrm{pH}, \mathrm{PaCO} 2 / \mathrm{PaO} 2$, Base Excess & $126 / 139(90.6 \%)$ & $69 / 72(95.8 \%)$ & $25 / 28(89.3 \%)$ & $3 / 5(60 \%)$ & 29/34 (85.3\%) \\
\hline Sodium/Potassium & $126 / 139(90.6 \%)$ & $69 / 72(95.8 \%)$ & $24 / 28(85.7 \%)$ & $3 / 5(60 \%)$ & $30 / 34(88.2 \%)$ \\
\hline Glucose & $123 / 139(88.5 \%)$ & $68 / 72(94.4 \%)$ & $23 / 28(82.1 \%)$ & $3 / 5(60 \%)$ & 29/34 (85.3\%) \\
\hline Haemoglobin & $116 / 139(83.5 \%$ & $67 / 72(93 \%)$ & $21 / 28(75 \%)$ & $3 / 5(60 \%)$ & 25/34 (73.5\%) \\
\hline Calcium & 107/139 (77\%) & 62/72 (86.1\%) & 19/28 (67.9\%) & $3 / 5(60 \%)$ & 23/34 (67.6\%) \\
\hline Bilirubin & 46/139 (33.1\%) & 25/72 (34.7\%) & 11/28 (39.3\%) & $1 / 5(20 \%)$ & 9/34 (26.5\%) \\
\hline Phosphate & 27/139 (19.2\%) & 18/72 (25\%) & 2/28 (7.1\%) & $1 / 5(20 \%)$ & 6/34 (17.6\%) \\
\hline Other: & $23 / 139(16.5 \%)$ & $18 / 72(25 \%)$ & $3 / 28(10.7 \%)$ & $0 / 5(0 \%)$ & 2/34 (5.9\%) \\
\hline
\end{tabular}

ED Emergency Department, PAU Paediatric Assessment Unit, UCC Urgent Care Centre, hCG human Chorionic Gonadotrophin, RSV Respiratory Syncytial Virus, CRP C-reactive protein

which case POCT may conversely delay admission. A formal evaluation of these two approaches would help determine the utility of POCT in this situation. However, it must be recognised that determining viral aetiology is useful for public health surveillance and it is likely that ward based testing will still need to occur.

For influenza, one study of the use of POCT in febrile children showed no difference in physician management, cost, or length of stay in the paediatric Emergency Department (ED) [7]. However, a positive POCT for influenza was associated with a significant reduction in urine and blood cultures being sent for febrile children [18].

Some studies have recommended use of rapid streptococcal A infection testing for patients with a sore throat, citing reduction of antimicrobial use $[19,20]$. However, in England, this is not routinely recommended by $\mathrm{Na}$ tional Institute of Health and Care Excellence (NICE) guidance, as this approach is unlikely to be costeffective. Their limited role in improving antimicrobial prescribing and stewardship, as well as patient outcomes, when compared to clinical scores alone [21] is the likely reason for the low use in surveyed sites.

In relation to biomarkers for infection, a systematic review and cost-effectiveness analysis evaluated whether Procalcitonin testing was helpful in guiding antibiotic therapy for sepsis in intensive care and ED settings [22, 23]. This concluded that addition of a Procalcitonin based algorithm to antibiotic guidance could be useful in reducing antibiotic exposure and length of hospital stay safely in adults [22]. Clinicians might infer that similar results may be seen in children, however high quality evidence is lacking, and further research is needed on the utility of Procalcitonin in this domain.

The most common source of funding for POCT was sustainable long term funding as part of an ongoing service commitment for well-established POCT; these included blood gas analysis, urinalysis and blood sugar testing, and are routinely used in $>90 \%$ of departments. The newer POCT were more likely to be funded using temporary funds as part of a service evaluation, through charitable funding and/ or donations or as part of an industry sponsored trial.

Given our findings regarding the challenges of implementing new POCT, robust evidence for patient benefit is required in order to provide a clear case to justify $\mathrm{Na}$ tional Health Service (NHS) spending on the testing equipment and consumables required to use in routine clinical practice.

We acknowledge the limitations of a survey based qualitative study but believe our response rate and reach 
Table 2 Staff members responsible for performing and acting on POCT results

\begin{tabular}{|c|c|c|c|c|c|c|c|c|}
\hline \multicolumn{9}{|c|}{ Staff members who perform each POCT } \\
\hline & $\begin{array}{l}\text { Clinical } \\
\text { Nurse }\end{array}$ & $\begin{array}{l}\text { Healthcare } \\
\text { assistant }\end{array}$ & ENP/ACP & \multicolumn{2}{|l|}{ Junior Doctor } & Consultant & Other & Total \\
\hline Blood sugar & $\begin{array}{l}135 / 325 \\
(41.5 \%)\end{array}$ & $2 / 325(0.6 \%)$ & $\begin{array}{l}71 / 325 \\
(21.8 \%)\end{array}$ & \multicolumn{2}{|l|}{$61 / 325(18.8 \%)$} & $\begin{array}{l}54 / 325 \\
(16.6 \%)\end{array}$ & $\begin{array}{l}2 / 325 \\
(0.6 \%)\end{array}$ & $\begin{array}{l}325 \\
(100 \%)\end{array}$ \\
\hline Urinalysis & $\begin{array}{l}134 / 444 \\
(30.2 \%)\end{array}$ & $87 / 444(19.6 \%)$ & $\begin{array}{l}85 / 444 \\
(19.1 \%)\end{array}$ & \multicolumn{2}{|l|}{$74 / 444(16.7 \%)$} & $\begin{array}{l}59 / 444 \\
(13.3 \%)\end{array}$ & $\begin{array}{l}5 / 444 \\
(1.1 \%)\end{array}$ & $\begin{array}{l}444 \\
(100 \%)\end{array}$ \\
\hline $\begin{array}{l}\text { Blood gas } \\
\text { analysis }\end{array}$ & $\begin{array}{l}107 / 471 \\
(22.7 \%)\end{array}$ & $46 / 471(9.8 \%)$ & $\begin{array}{l}86 / 471 \\
(18.3 \%)\end{array}$ & \multicolumn{2}{|l|}{$121 / 471(25.7 \%)$} & $\begin{array}{l}109 / 471 \\
(23.1 \%)\end{array}$ & $\begin{array}{l}2 / 471 \\
(0.4 \%)\end{array}$ & $\begin{array}{l}471 \\
(100 \%)\end{array}$ \\
\hline Blood Ketones & $\begin{array}{l}120 / 292 \\
(41.1 \%)\end{array}$ & 0/292 (0\%) & $70 / 292(24 \%)$ & \multicolumn{2}{|l|}{ 52/292 (17.8\%) } & $\begin{array}{l}47 / 292 \\
(16.1 \%)\end{array}$ & $3 / 292(1 \%)$ & $\begin{array}{l}292 \\
(100 \%)\end{array}$ \\
\hline $\begin{array}{l}\text { Urinary Beta } \\
\text { HCG }\end{array}$ & $\begin{array}{l}115 / 350 \\
(32.9 \%)\end{array}$ & $86 / 350(24.6 \%)$ & $70 / 350(20 \%)$ & \multicolumn{2}{|l|}{$43 / 350(12.3 \%)$} & $\begin{array}{l}34 / 350 \\
(9.7 \%)\end{array}$ & $\begin{array}{l}2 / 350 \\
(0.6 \%)\end{array}$ & $\begin{array}{l}350 \\
(100 \%)\end{array}$ \\
\hline Influenza & $\begin{array}{l}45 / 105 \\
(42.9 \%)\end{array}$ & 19/105 (18.1\%) & $22 / 105(21 \%)$ & \multicolumn{2}{|l|}{$10 / 105(9.5 \%)$} & 9/105 (8.6\%) & 0/105 (0\%) & $\begin{array}{l}105 \\
(100 \%)\end{array}$ \\
\hline RSV & $\begin{array}{l}39 / 84 \\
(46.4 \%)\end{array}$ & 14/84 (16.7\%) & $\begin{array}{l}17 / 84 \\
(20.2 \%)\end{array}$ & \multicolumn{2}{|l|}{$7 / 84(8.3 \%)$} & $5 / 84(6 \%)$ & $2 / 84(2.4 \%)$ & $\begin{array}{l}84 \\
(100 \%)\end{array}$ \\
\hline CRP & $6 / 43(14 \%)$ & $2 / 43(4.7 \%)$ & $\begin{array}{l}11 / 43 \\
(25.6 \%)\end{array}$ & \multicolumn{2}{|l|}{$13 / 43(30.2 \%)$} & $\begin{array}{l}11 / 43 \\
(25.6 \%)\end{array}$ & $0 / 43(0 \%)$ & $\begin{array}{l}43 \\
(100 \%)\end{array}$ \\
\hline GAS & $4 / 14(28.6 \%)$ & $3 / 14(21.4 \%)$ & $3 / 14(21.4 \%)$ & \multicolumn{2}{|l|}{$2 / 14(14.3 \%)$} & $2 / 14(14.3 \%)$ & $0 / 14(0 \%)$ & $\begin{array}{l}14 \\
(100 \%)\end{array}$ \\
\hline Pct & $0 / 4(0 \%)$ & $0 / 4(0 \%)$ & $0 / 4(0 \%)$ & \multicolumn{2}{|l|}{ 2/4 (50\%) } & $2 / 4(50 \%)$ & $0 / 4(0 \%)$ & $4(100 \%)$ \\
\hline Total & $\begin{array}{l}705 / 2132 \\
(33.1 \%)\end{array}$ & $\begin{array}{l}259 / 2132 \\
(12.1 \%)\end{array}$ & $\begin{array}{l}435 / 2132 \\
(20.4 \%)\end{array}$ & \multicolumn{2}{|l|}{ 385/2132 (18.1\%) } & $\begin{array}{l}332 / 2132 \\
(15.6 \%)\end{array}$ & $\begin{array}{l}16 / 2132 \\
(0.8 \%)\end{array}$ & $\begin{array}{l}2132 \\
(100 \%)\end{array}$ \\
\hline \multicolumn{9}{|c|}{ Staff who are responsible for acting on POCT results } \\
\hline & $\begin{array}{l}\text { Clinical } \\
\text { Nurse }\end{array}$ & $\begin{array}{l}\text { Healthcare } \\
\text { assistant }\end{array}$ & ENP/ACP & $\begin{array}{l}\text { Junior Trainee (eg } \\
\text { ST1-3) }\end{array}$ & $\begin{array}{l}\text { Senior non-Consultant } \\
\text { (eg ST4+) }\end{array}$ & Consultant & Other & Total \\
\hline Blood sugar & $\begin{array}{l}97 / 601 \\
(16.1 \%)\end{array}$ & 10/601 (1.7\%) & $\begin{array}{l}93 / 601 \\
(15.5 \%)\end{array}$ & $132 / 601(22 \%)$ & $135 / 601(22.5 \%)$ & $\begin{array}{l}132 / 601 \\
(22 \%)\end{array}$ & $\begin{array}{l}2 / 601 \\
(0.3 \%)\end{array}$ & $\begin{array}{l}601 \\
(100 \%)\end{array}$ \\
\hline Urinalysis & $\begin{array}{l}59 / 555 \\
(10.6 \%)\end{array}$ & $13 / 555(2.3 \%)$ & $\begin{array}{l}91 / 555 \\
(16.4 \%)\end{array}$ & $128 / 555(23.1 \%)$ & $132 / 555(23.8 \%)$ & $\begin{array}{l}130 / 555 \\
(23.4 \%)\end{array}$ & $\begin{array}{l}2 / 555 \\
(0.4 \%)\end{array}$ & $\begin{array}{l}555 \\
(100 \%)\end{array}$ \\
\hline $\begin{array}{l}\text { Blood gas } \\
\text { analysis }\end{array}$ & $\begin{array}{l}33 / 493 \\
(67.5 \%)\end{array}$ & $4 / 493(0.8 \%)$ & $\begin{array}{l}80 / 493 \\
(16.2 \%)\end{array}$ & $120 / 493(24.3 \%)$ & $127 / 493(25.8 \%)$ & $\begin{array}{l}127 / 493 \\
(25.8 \%)\end{array}$ & $\begin{array}{l}2 / 493 \\
(0.4 \%)\end{array}$ & $\begin{array}{l}493 \\
(100 \%)\end{array}$ \\
\hline $\begin{array}{l}\text { Blood } \\
\text { Ketones }\end{array}$ & $\begin{array}{l}62 / 522 \\
(11.9 \%)\end{array}$ & $8 / 522(1.5 \%)$ & $\begin{array}{l}86 / 522 \\
(16.5 \%)\end{array}$ & $118 / 522(22.6 \%)$ & $124 / 522(23.8 \%)$ & $\begin{array}{l}123 / 522 \\
(23.6 \%)\end{array}$ & $\begin{array}{l}1 / 522 \\
(0.2 \%)\end{array}$ & $\begin{array}{l}522 \\
(100 \%)\end{array}$ \\
\hline $\begin{array}{l}\text { Urinary Beta } \\
\text { hCG }\end{array}$ & $\begin{array}{l}44 / 465 \\
(9.5 \%)\end{array}$ & $8 / 465(1.7 \%)$ & $\begin{array}{l}78 / 465 \\
(16.8 \%)\end{array}$ & $109 / 465(23.4 \%)$ & $113 / 465(24.3 \%)$ & $\begin{array}{l}111 / 465 \\
(23.9 \%)\end{array}$ & $\begin{array}{l}2 / 465 \\
(0.4 \%)\end{array}$ & $\begin{array}{l}465 \\
(100 \%)\end{array}$ \\
\hline Influenza & $\begin{array}{l}34 / 206 \\
(16.5 \%)\end{array}$ & $7 / 206(3.4 \%)$ & $35 / 206(17 \%)$ & 40/206 (19.4\%) & $45 / 206(21.8 \%)$ & $\begin{array}{l}44 / 206 \\
(21.4 \%)\end{array}$ & $\begin{array}{l}1 / 206 \\
(0.5 \%)\end{array}$ & $\begin{array}{l}206 \\
(100 \%)\end{array}$ \\
\hline RSV & $\begin{array}{l}32 / 181 \\
(17.7 \%)\end{array}$ & $3 / 181(1.7 \%)$ & $29 / 181(16 \%)$ & 36/181 (19.9\%) & 40/181 (22.1\%) & $\begin{array}{l}40 / 181 \\
(22.1 \%)\end{array}$ & $\begin{array}{l}1 / 181 \\
(0.6 \%)\end{array}$ & $\begin{array}{l}181 \\
(100 \%)\end{array}$ \\
\hline CRP & 0/48 (0\%) & 0/48 (0\%) & $\begin{array}{l}10 / 48 \\
(20.8 \%)\end{array}$ & $12 / 48(25 \%)$ & 13/48 (27.1\%) & $\begin{array}{l}13 / 48 \\
(27.1 \%)\end{array}$ & 0/48 (0\%) & $\begin{array}{l}48 \\
(100 \%)\end{array}$ \\
\hline GAS & $0 / 19(0 \%)$ & $0 / 19(0 \%)$ & $4 / 19(21.1 \%)$ & $5 / 19(26.3 \%)$ & $5 / 19(26.3 \%)$ & $5 / 19(26.3 \%)$ & 0/19 (0\%) & $\begin{array}{l}19 \\
(100 \%)\end{array}$ \\
\hline Pct & $0 / 7(0 \%)$ & $0 / 7(0 \%)$ & $1 / 7(14.3 \%)$ & $2 / 7(28.6 \%)$ & $2 / 7(28.6 \%)$ & $2 / 7(28.6 \%)$ & $0 / 7(0 \%)$ & 7 (100\%) \\
\hline Total & $\begin{array}{l}361 / 3097 \\
(11.7 \%)\end{array}$ & $53 / 3097(1.7 \%)$ & $\begin{array}{l}507 / 3097 \\
(16.4 \%)\end{array}$ & 702/3097 (22.7\%) & 736/3097 (23.8\%) & $\begin{array}{l}727 / 3097 \\
(23.5 \%)\end{array}$ & $\begin{array}{l}11 / 3097 \\
(0.4 \%)\end{array}$ & $\begin{array}{l}3097 \\
(100 \%)\end{array}$ \\
\hline
\end{tabular}

POCT Point-of-Care Test, ENP Emergency nurse practitioner, ANP Advanced nurse practitioner, ST Specialty trainee, hCG human Chorionic Gonadotrophin, RSV Respiratory Syncytial Virus, CRP C-reactive protein, GAS Group A Streptococcus, Pct Procalcitonin

were sufficient to avoid significant bias. We acknowledge that some operator training and quality control have been identified as barriers to adoption and we didn't ask focused questions on these. This was a point-in-time survey and it is likely that the situation in many departments may be different now than at the time the survey 


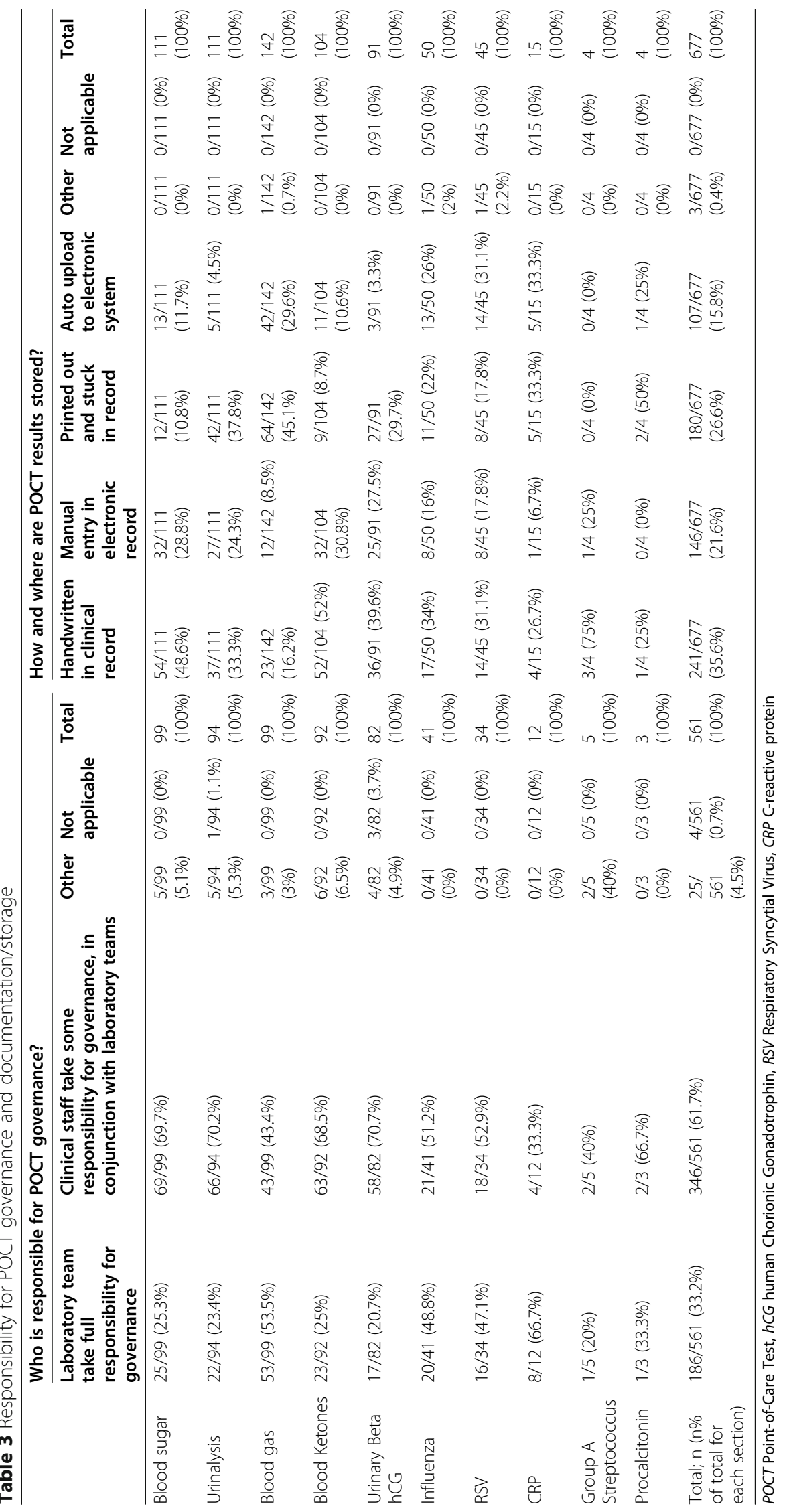


Table 4 Obstacles to introduction of POCT and sources of current POCT funding in units

\begin{tabular}{lll}
\hline Obstacles currently existing to the use of POCT & $\mathbf{n}$ & \% of $\mathbf{1 5 8}$ responses \\
Difficulties with funding & 72 & $45.6 \%$ \\
Evidence is lacking for POCT & 33 & $20.9 \%$ \\
Nobody will take responsibility for the governance of the test & 20 & $12.7 \%$ \\
Nobody has time to perform the quality control testing & 16 & $10.1 \%$ \\
Other & 12 & $7.6 \%$ \\
Nobody has time to run the test & 5 & $3.2 \%$ \\
Total & $\mathbf{1 5 8}$ & $\mathbf{1 0 0 \%}$ \\
Sources of current POCT funding & & $\mathbf{9 8}$ responses \\
All funded as part of ongoing service with sustainable longterm funding & 81 & $10.7 \%$ \\
Some funded using temporary fund as part of a service evaluation & 10 & $10.2 \%$ \\
Some funded through charitable funding and/or donations & 5 & $5.1 \%$ \\
Some funded as part of an industry sponsored trial & 1 & $1 \%$ \\
Other & 1 & $\mathbf{1 0 0 \%}$ \\
Total & $\mathbf{9 8}$ & $1 \%$
\end{tabular}

was undertaken. However we hope our identification of domains of interests will be useful for future evaluation and research.

In summary, if new POCT are to be introduced, it is vital that all stakeholders are involved in the decision making including clinical and laboratory teams, patients, regulatory authorities and insurers. Sustainability will depend on sound evidence base and financial viability [24].

\section{Conclusions}

The use of POCT for blood glucose, blood gas, urinalysis and blood ketones is widespread among UK Children's Emergency Departments and Assessment units, however newer biomarkers tests are used less often, including those for pathogen identification. Variation exists both in unit practices, and the governance of POCT. A clear strategy to overcome the key obstacles of funding, evidence base, and standardising variation will be essential if there is a drive toward increasing implementation of POCT.

\begin{abstract}
Abbreviations
GAPRUKI: General and Adolescent Paediatric Research UK and Ireland; PERUKI: Paediatric Emergency Research UK and Ireland; PEMLA group: Paediatric Emergency Medicine Leicester Academic Group; SAPPHIRE Group: Social Science Applied to Healthcare Improvement Research; POCT: Point-Of-Care Testing; UK: United Kingdom; RSV: Respiratory Syncytial Virus; CRP: C - Reactive Protein; PCT: Procalcitonin; CHERRIES: Checklist for Reporting Results of Internet E-Surveys; REDCap: Research Electronic Data Capture tools; ENP: Emergency Nurse Practitioners; ANP: Advanced Nurse Practitioners; hCG: human Chorionic Gonadotropin; ED: Emergency Department; NICE: National Institute of Health and Care Excellence; NHS: National Health Service; PAU: Paediatric Assessment Unit; UCC: Urgent Care Centre; ST: Specialty trainee; GAS: Group A Streptococcus; IP: Inpatient
\end{abstract}

\section{Supplementary Information}

The online version contains supplementary material available at https:/doi. org/10.1186/s12873-021-00556-7.
Additional file 1.

Additional file 2.

\section{Acknowledgements}

The following individuals acted as site study leads for PERUKI and/or GAPRUKI in their institution, as listed:

Adrian Boyle, Peter Heinz (Addenbrooke's Hospital, Cambridge, England); Shrouk Messahel, Dan Hawcutt (Alder Hey Children's Hospital NHS

Foundation Trust, Liverpool, England); Caroline Ponmani (Barking, Havering \& Redbridge University Hospitals NHS Trust, England); Chris Bird, Deepthi

Jyothish (Birmingham Children's Hospital, Birmingham, England); Catherine Williams (Bolton NHS Foundation Trust, Bolton, England); Ronan O'Sullivan (Bon Secours Hospital, Cork, Ireland); Elizabeth Jones (Bradford Royal Infirmary, Bradford, England); Mark Lyttle, Nwanneka Sargant (Bristol Royal Hospital for Children Bristol, England); James Ross (Chelsea \& Westminster NHS Foundation Trust, London, England); Michael Barrett, Sinead Harty (Children's Health Ireland at Crumlin, Dublin, Ireland); Turlough Bolger, David Coghlan (Children's Health Ireland at Tallaght, Dublin, Ireland); Patrick Fitzpatrick, Conor Hensey (Children's Health Ireland at Temple Street, Dublin, Ireland); Tim Hussan (County Durham \& Darlington NHS Foundation Trust, England); Kate Charlick (Derriford Hospital, Plymouth, England); William Verling (Dorset County Hospital, Dorset, England); Peter Christian (East Kent Hospital, England); Matthew Clark (East Sussex NHS Health Trust, England); Bhavni Shah (Epsom General Hospital, Epsom, England); John Criddle, Ronny Cheung (The Evelina London Children's Hospital, London, England); Roger Alcock (Forth Valley Hospital, Larbert, Scotland); Patrick Aldridge (Frimley Park Hospital, Frimley, England); Russell Peek (Gloucestershire Hospitals NHS Foundation Trust, Gloucester, England); Mark Anderson (Great North Children's Hospital, Newcastle-upon-Tyne, England); Elizabeth Herrieven (Hull Royal Infirmary, Hull, England); Katherine Jerman, Arshid Murad (James Cook University Hospital, Middlesbrough, England); Charlotte Brown, Andy Marshall (John Radcliffe Hospital, Oxford, England); Fleur Cantle (Kings College Hospital, London, England); Gavin Wilson (Kingston Hospital NHS Foundation Trust, Kingston-upon-Thames, England); Alice Downes (Leeds General Infirmary, Leeds, England); Damian Roland, Srini Bandi (Leicester Royal Infirmary, Leicester, England); Adebayo Da-Costa (Medway Hospital NHS Foundation Trust, Gillingham, England); Ray Barry (Mercy University Hospital, Cork, Ireland); Natasha De Vere (The Mid Yorkshire Hospitals NHS Trust, England); Clare Dieppe (Morriston Hospital, Swansea, Wales); Jane Evans (Norfolk \& Norwich University Hospital, Norwich, England); Gayle Hann, Clare Tipper (North Middlesex Hospital, London, England); Bengisu Bassay (Northampton General Hospital, England); Dermot Dalton (Northern Devon Healthcare NHS Trust, 
Barnstaple, England); Lauren Fraser (Northwick Park Hospital, London, England); Chris Gough (Nottingham University Hospitals NHS Trust, Nottingham England); Sharryn Gardner (Ormskirk \& District General Hospital, Ormskirk, England); Mark Tighe (University Hospitals Dorset, Dorset, England); Darren Ranasinghe, Simon Birch (Queen Alexandra Hospital, Portsmouth, England); Sharon Hall (Queen Elizabeth Hospital, Woolwich, England); Gareth Patton, Steve Turner (Royal Aberdeen Children's Hospital, Aberdeen, Scotland); Emily Walton (Royal Alexandra Children's Hospital, Brighton, England); Julie-Ann Maney, Tom Bourke (Royal Belfast Hospital for Sick Children, Belfast, Northern Ireland); Manish Thakker (Royal Berkshire NHS Foundation Trust, Reading, England); Gisela Robinson, Lizzie Starkey (Royal Derby Hospital, Derby, England); Andrew Appelboam (Royal Devon \& Exeter Hospital, Exeter, England); Shye Wei Wong (Royal Free Hospital, London, England); Steven Foster, Louisa Pollock (Royal Hospital for Children, Glasgow, Scotland); Jen Browning (Royal Hospital for Children \& Young People, Edinburgh, Scotland): Katherine Potier (Royal Manchester Children's Hospital, Manchester, England); Kirsty Challen (Royal Preston Hospital, Preston, England); Elizabeth Gillby (Royal United Hospital, Bath, England); Lisa Kehler (Royal Wolverhampton NHS Trust, Wolverhampton, England); Sebastian Gray (Salisbury NHS Foundation Trust, Salisbury, England); Shammi Ramlakhan (Sheffield Children's NHS Foundation Trust, Sheffield, England); Niall Mullen (South Tyneside \& Sunderland NHS Foundation Trust, Sunderland, England); Jane Bayreuther, Katrina Cathie (Southampton Children's Hospital, Southampton, England); Heather Jarman (St George's University Hospitals NHS Foundation Trust, London, England); Neil Thompson (St Mary's Hospital, Imperial College Healthcare NHS Trust, London, England); Ami Parikh (The Royal London Hospital, London, England); Siba Paul (Torbay Hospital, England); Sarah Trippick, Alastair Sutcliffe (University College Hospital London, England); Joanne Mulligan (University Hospital Crosshouse, Kilmarnock, Scotland); Sophie Keers (University Hospital Lewisham, London, England); Jeff Morgan (University Hospital of Wales, Cardiff, Wales) Michelle Jacobs (Watford General Hospital, Watford, England); Mike Linney (Western Sussex Hospitals NHS Trust, Chichester, England); Sarah Wilson (Wexham Park Hospital, Slough, England); Erum Jamall (Whittington Health NHS Trust, London, England).

In addition we thank Mai Baquedano (University Hospitals Bristol and Weston NHS Foundation Trust) for her assistance with construction of the study survey, and data management.

"What is already known on this topic"

- POCT has been explored as an adjunctive tool in clinical decision making for a number of acute conditions

- POCT can potentially help in earlier treatment initiation, improved patient outcomes, patient satisfaction, and patient flow through the emergency department but the evidence for benefit to patients is limited.

- Further larger research studies are required to evaluate the newer POCT in more detail.

"What this study adds"

- Among acute paediatric settings, commonly used POCT include blood gases, urinalysis and blood sugar testing, whilst newer POCT such as inflammatory biomarkers and pathogen identification are less frequently used

- POCT is mostly processed and interpreted by clinical teams, though there is wide variation in their governance

- The most commonly perceived obstacles to the use of POCT are lack of funding, evidence base, and infrastructure to support test performance and quality assurance

\section{Authors' contributions}

ML, KC, AM, TW and DR made substantial contributions to the conception/ design of the work; MP performed the statistical analysis and wrote the initial draft; all authors were involved in the acquisition, analysis, and interpretation of data; all authors read and approved the final manuscript.

\section{Funding}

None.

\section{Availability of data and materials}

All data generated or analysed during this study are included in this published article [and its supplementary information files].

\section{Declarations}

\section{Ethics approval and consent to participate}

As this survey study contained no patient level data, and was distributed using professional collaborative professional networks, ethical approval was unnecessary according to the Health Research Authority framework decision tool.

Patients were not included in the survey; therefore formal consent to participate was not needed. By agreeing to participate in the survey, the consent was presumed by the participating health professional.

\section{Consent for publication}

Not applicable.

\section{Competing interests}

The authors declare that they have no competing interests.

\section{Author details}

${ }^{1}$ Paediatric Emergency Medicine Leicester Academic (PEMLA) Group, Children's Emergency Department, Leicester Royal Infirmary, Leicester, UK. ${ }^{2}$ Emergency Department, Bristol Royal Hospital for Children, Bristol, UK. ${ }^{3}$ Faculty of Health and Applied Sciences, University of the West of England, Bristol, UK. ${ }^{4}$ Department of Child Health, University Hospital Southampton NHS Foundation Trust, Southampton, UK. ${ }^{5}$ National Institute of Health Research Southampton Clinical Research Facility and Biomedical Research Centre, University Hospital Southampton NHS Foundation Trust,

Southampton, UK. ${ }^{6}$ Wellcome-Wolfson Institute for Experimental Medicine, Queen's University Belfast, Belfast, UK. 'Emergency Department, Children's Health Ireland, Temple Street, Dublin, Ireland. ${ }^{8}$ SAPPHIRE Group, Health Sciences, Leicester University, Leicester, UK.

Received: 28 May 2021 Accepted: 10 November 2021

Published online: 11 January 2022

\section{References}

1. Woo J, McCabe JB, Chauncey D, Schug T, Henry JB. The evaluation of a portable clinical analyzer in the emergency department. Am J Clin Pathol. 1993;100:599

2. Sands VM, Auerbach PS, Birnbaum J, Green M. Evaluation of a Portable Clinical Blood Analyzer in the Emergency Department. Acad Emerg Med. 1995;2:172.

3. Lee-Lewandrowski E, Corboy D, Lewandrowski K, Sinclair J, McDermot S, Benzer TI. Implementation of a point-of-care satellite laboratory in the emergency department of an academic medical center: impact on test turnaround time and patient emergency department length of stay. Arch Pathol Lab Med. 2003;127(4):456-60. https://doi.org/10.5858/2003-127-0456IOAPSL.

4. Parvin CA, Lo SF, Deuser SM, Weaver LG, Lewis LM, Scott MG. Impact of point-of-care testing on patients' length of stay in a large emergency department. Clin Chem. 1996:42:711.

5. Larsson A, Greig-Pylypczuk R, Huisman A. The state of point-of-care testing: a european perspective. Ups J Med Sci. 2015;120(1):1-10. https://doi.org/1 0.3109/03009734.2015.1006347.

6. Kendall J, Reeves B, Clancy M. Point of care testing: randomised controlled trial of clinical outcome. Br Med J. 1998;316(7137):1052-7. https://doi.org/1 0.1136/bmj.316.7137.1052.

7. Quinn AD, Dixon D, Meenan BJ. Barriers to hospital-based clinical adoption of point-of-care testing (POCT): a systematic narrative review. Crit Rev Clin Lab Sci. 2016;53(1):1-12. https://doi.org/10.3109/10408363.2015.1054984.

8. FitzGibbon F, Huckle D, Meenan BJ. Barriers affecting the adoption of pointof-care technologies used in chest pain diagnosis within the UK National Health Service: part 1-user issues. Point Care. 2010;9(2):70-9. https://doi. org/10.1097/POC.0b013e3181d9d7f8.

9. Turner PJ, van den Bruel A, Jones CHD, Plüddemann A, Heneghan C, Thompson MJ, et al. Point-of-care testing in UK primary care: a survey to establish clinical needs. Fam Pract. 2016;33(4):388-94. https://doi.org/10.1 093/fampra/cmw018.

10. Dahm MR, McCaughey E, Li L, Westbrook J, Mumford V, lles-Mann J, et al. Point-of-care testing across rural and remote emergency Departments in Australia: staff perceptions of operational impact. Stud Health Technol Inform. 2017;239:28. 
11. Rasti R, Nanjebe D, Karlström J, Muchunguzi C, Mwanga-Amumpaire J, Gantelius J, et al. Health care workers' perceptions of point-of-care testing in a low-income country - A qualitative study in Southwestern Uganda. PLoS One. 2017;12:e0182005.

12. Eysenbach G. Improving the quality of web surveys: the checklist for reporting results of internet E-surveys (CHERRIES). J Med Internet Res. 2004; 6(3). https://doi.org/10.2196/jmir.6.3.e34.

13. Lyttle MD, O'Sullivan R, Hartshorn S, Bevan C, Cleugh F, Maconochie I. Pediatric emergency research in the UK and Ireland (PERUKI): developing a collaborative for multicentre research. Arch Dis Child. 2014;99(6):602-3. https://doi.org/10.1136/archdischild-2013-304998.

14. Harris PA, Taylor R, Thielke R, Payne J, Gonzalez N, Conde JG. Research electronic data capture (REDCap)-a metadata-driven methodology and workflow process for providing translational research informatics support. J Biomed Inform. 2009:42(2):377-81. https://doi.org/10.1016/j.jbi.2008.08.010.

15. Harris PA, Taylor R, Minor BL, Elliott V, Fernandez M, O'Neal L, et al. The REDCap consortium: building an international community of software platform partners. J Biomed Inform. 2019;95:103208. https://doi.org/10.1016/ j.jbi.2019.103208.

16. Health Research Authority. Is my study research? Health Research Authority Web Page. 2017.

17. Mills JM, Harper J, Broomfield D, Templeton KE. Rapid testing for respiratory syncytial virus in a paediatric emergency department: benefits for infection control and bed management. J Hosp Infect. 2011;77(3):248-51. https://doi. org/10.1016/j.jhin.2010.11.019.

18. Patel P, Laurich VM, Smith S, Sturm J. Point-of-care influenza testing in the pediatric emergency department. Pediatric Emergency Care [Internet]. 2020 Nov 1 [cited 2021 Oct 12];36(11):515-8. Available from: https://journals.Iww. com/pec-online/Fulltext/2020/11000/Point_of_Care_Influenza_Testing_in_ the_Pediatric.2.aspx

19. Reinert R R. Rapid streptococcal antigen detection tests. Laboratoriums Medizin/J Lab Medicine 2007;31(6):280-93.

20. Stürenburg E, Junker R. Point-of-care testing in microbiology - The advantages and disadvantages of immunochromatographic test strips. Deutsches Arzteblatt. 2009;106:48

21. Turner PJ, Heneghan C, Price CP, Yang Y, van den Bruel A, Plüddemann A. Point-of-care tests for group A streptococcus. Diagnostic Evidence Cooperative Oxford. 2015.

22. National Institute for Health and Care Excellence. Procalcitonin testing for diagnosing and monitoring sepsis (ADVIA Centaur BRAHMS PCT assay, BRAHMS PCT Sensitive Kryptor assay, Elecsys BRAHMS PCT assay, LIAISON BRAHMS PCT assay and VIDAS BRAHMS PCT assay). DG 18. 2015;(October): $1-22$.

23. Version R. Biomarker-guided duration of Antibiotic Treatment in Children Hospitalised with confirmed or suspected bacterial infection (BATCH Trial). 2020;0-67. Available from: https://www.isrctn.com/ISRCTN11369832

24. Luppa PB, Müller C, Schlichtiger A, Schlebusch H. Point-of-care testing (POCT): current techniques and future perspectives. Trends Analytical Chem 2011;30(6):887-98. https://doi.org/10.1016/j.trac.2011.01.019.

\section{Publisher's Note}

Springer Nature remains neutral with regard to jurisdictional claims in published maps and institutional affiliations.

Ready to submit your research? Choose BMC and benefit from:

- fast, convenient online submission

- thorough peer review by experienced researchers in your field

- rapid publication on acceptance

- support for research data, including large and complex data types

- gold Open Access which fosters wider collaboration and increased citations

- maximum visibility for your research: over $100 \mathrm{M}$ website views per year

At BMC, research is always in progress.

Learn more biomedcentral.com/submissions 